\title{
Early bilinguals and adult heritage speakers: What are the links? ${ }^{1}$
}

\author{
Carmen Silva-Corvalán* \\ University of Southern California, EE.UU.
}

\begin{abstract}
A central concern of scholars of bilingualism is the extent and causes of phenomena that seemingly result from the close contact of two (or more) grammatical systems. Societal bilingualism is characterized by constant and rapid changes which may be observed as they arise and spread in the linguistic and social systems. Likewise, bilingual first language acquisition is characterized by constant changes as children become cognitively and linguistically more mature. This article compares aspects of the grammars of two developing English-Spanish bilinguals with those of adult bilinguals in order to examine the general issue of intergenerational continuity and change in a situation of societal bilingualism. Two types of contact-induced change are identified: copy, a qualitative mechanism that underlies the notion of transfer, and quantitative influence, that is, patterns that are frequent in one language affect the frequency of parallel patterns in a
\end{abstract}

\footnotetext{
1 This is a slightly modified version of a plenary lecture presented at the Linguistic Society of America 89th Annual Meeting in Portland (Oregon, USA), January 9, 2015. For valuable comments on the earlier version I would like to thank Ricardo Otheguy, Andrew Lynch, Ed Finegan, Naomi L. Shin, and Kim Potowski.

૫Para correspondencia, dirigirse a: Carmen Silva-Corvalán (csilva@usc.edu), University of Southern California, University Park Ave, THH-156, Los Angeles, California, USA 900890358 .
} 
contact language. Changes caused by copying are clearly the result of contact, while those that result from influence may have an internal or an external motivation, or both. The study supports the hypothesis that crosslinguistic interaction affects the lexicon and discoursepragmatics, but not the core syntax of the languages. Some concrete connections are indentified between early bilingual grammars and those of adult bilinguals, namely the increased production of overt subject pronouns and preverbal subjects, a reduced verbal system, and the reproduction of the meaning of word combinations from English into Spanish. The theoretical implications of the parallels identified between the children's linguistic behavior and that of adult bilinguals are discussed.

Keywords: Spanish, English, simultaneous bilinguals, heritage speakers, crosslinguistic interaction, linguistic change, grammatical subjects, verb system, lexical innovations.

\section{INFANTES BILINGÜES Y HABLANTES DE HERENCIA ADULTOS:}

¿QUÉ LOS VINCULA?

\section{Resumen}

Una preocupación central de los investigadores del bilingüismo es la magnitud y las causas de los fenómenos que aparentemente resultan del contacto de dos (o más) sistemas gramaticales. El bilingüismo social se caracteriza por cambios rápidos y constantes que se pueden observar a medida que surgen y se propagan en los sistemas lingüísticos y sociales. Del mismo modo, la adquisición de dos primeras lenguas se caracteriza por cambios constantes a medida que los niños desarrollan mayor madurez cognitiva y lingüística. Este artículo compara algunos aspectos de las gramáticas de dos bilingües que están adquiriendo simultáneamente inglés y español, con aspectos de las gramáticas de adultos bilingües con el propósito de examinar la cuestión de la continuidad intergeneracional y del cambio. Se identifican dos tipos de cambio inducidos por el contacto lingüístico: copia, un mecanismo cualitativo que subyace a la noción de transferencia, e influencia cuantitativa, es decir, patrones que son frecuentes en un idioma afectan la frecuencia de los patrones paralelos en una lengua de contacto. Los cambios causados por copias son claramente el resultado de contacto, mientras que los que resultan de influencia pueden tener una motivación interna o externa, o ambas. El estudio apoya la hipótesis de que la interacción interlingüística afecta el léxico y la pragmática discursiva, pero no la sintaxis nuclear. Aspectos comunes entre las gramáticas de los niños y las de los adultos bilingües incluyen el gran número de pronombres 
sujeto explícitos y de sujetos preverbales, el sistema verbal reducido y la reproducción del significado de construcciones léxicas del inglés en el español. Se discuten las implicaciones teóricas de los paralelos identificados entre el comportamiento lingüístico de los niños y el de los bilingües adultos.

Palabras clave: español, inglés, bilingües simultáneos, hablantes de herencia, interacción interlingüística, cambio lingüístico, sujetos gramaticales, sistema verbal, innovaciones léxicas.

Recibido: 20/02/14

Aceptado: 12/04/15

\section{INTRODUCTION}

The possibility to observe language change in progress is an important motivation for the study of bilingual communities. Interestingly, some of the questions that stimulate animated debates in the fields of sociolinguistics, and historical and contact linguistics (cf. Thomason 2010) are also of concern to scholars of bilingual language acquisition. Thus, the transition from the study of adult bilinguals to that of child bilinguals, and the comparison of the language behaviors of these two groups should be quite natural.

Situations of societal bilingualism are characterized by constant and rapid changes which may be observed as they arise and spread in the linguistic and social systems. Likewise, bilingual first language acquisition (BFLA) is characterized by constant changes as children become cognitively and linguistically more mature. In this developmental process, simultaneous bilinguals appear to replicate but also diverge from their input models. In this article, I compare some of the features of the grammars of two developing English-Spanish bilinguals with those of adult bilinguals to examine the general issue of intergenerational continuity and change.

Specifically, I ask three related questions:

1. Bilinguals have been found to evidence crosslinguistic interaction phenomena, but are intergenerational changes the result of influence of one grammar over another or, rather, the outcome of internal developments constrained by the linguistic system of each of the languages in question, or by such cognitive mechanisms as processing economy? How is crosslinguistic interaction manifested in the speech 
of bilinguals (Argyri \& Sorace 2007; Müller \& Hulk 2001; Nicoladis 2012; Yip \& Mathews 2007)?

2. What is the effect of the amount of exposure to and use of the languages on the development of each of the bilinguals' language systems? (Gathercole \& Thomas 2009; Unsworth 2013 and forthcoming)

3. What is the relationship between the children's grammars and the more or less changed or reduced bilingual systems of adult 2nd and 3rd generation immigrants (usually referred to as "heritage speakers")? Are the reduced bilingual systems due to incomplete acquisition in the early years of a bilingual's life, or a result of processes of attrition or loss of acquired knowledge of the underused language? (Cuza 2010, Montrul 2005 and 2011)

Clearly, contact-induced change does occur; many words cross language boundaries, for example, but what about the morphosyntactic component? I show here that divergences from the input model in BFLA and innovative features in the languages of adult bilinguals do not violate the typological features or core grammar of the languages involved (see also Hickey 2010). My studies support the hypothesis that crosslinguistic interaction (also referred to as CLI) affects the lexicon and discourse-pragmatics.

Indeed, although community-based studies have identified simplification of some grammatical domains in a minority language (Gutiérrez 2003, Zentella 1997, among many), they have found scant evidence for contactinduced grammatical change (e.g., King 2000; Poplack \& Levey 2010; Poplack, Zentz \& Dion 2012; Silva-Corvalán 1994). The morphosyntactic component seems to be quite resistant to change (e.g., Silva-Corvalán 1998).

In my studies of bilingual children and adults I have identified two types of contact-induced changes involving the lexicon and discourse-pragmatics: copy, a qualitative mechanism that underlies the notion of transfer (cf. Doğruöz and Backus 2009) $)^{2}$, and quantitative influence, that is, patterns that are frequent in one language affect the frequency of parallel patterns in a contact language.

BFLA research has shown that simultaneous bilinguals evidence a numerical preference in the weaker language for a structure that has a parallel

2 The term transfer is generally used in the literature on bilingualism, but a more appropriate term is copy, since nothing is moved from one language to another. For example, the word "bye" remains in English while it is at the same time used in Spanish in the US, that is, "bye" has been copied from English into Spanish, and not transferred. 
in the stronger language. While this type of quantitative influence does not result in the production of non-target structures, qualitative copying may give rise to word combinations that do not exist in monolingual grammars. I will examine some of the factors that seem to trigger these interaction mechanisms in the acquisition of English and Spanish as first languages, and will show commonalities with what is also characteristic of the speech of adult bilinguals.

Importantly, it needs to be kept in mind that I have studied bilingualism in a situation of language inequality, English-Spanish bilingualism in Los Angeles. Thus, my findings should be interpreted with reference to a community characterized by the shift from Spanish to English across generations, and to a type of situation in which one language is subordinate to a socially and linguistically predominant one. In the process of shifting from Spanish to English at the societal level, and under the cognitive and social pressure from a dominant language at the individual level, speakers do not modify the typological patterns or core syntax of the receding language. Syntactic copying is rare, and when it occurs, the copied patterns do not seem to be passed on to the next generation (Otheguy 2003). Although based on studies of Spanish-English bilingualism, my observations could also be valid for other similar situations of bilingualism and language contact around the world.

\section{THE CHILDREN}

I have examined bilingual acquisition primarily in a corpus of data obtained during the first six years of life of two English-Spanish developing bilingual siblings, my grandsons Nico and Brennan (Silva-Corvalán 2014). Nico and Brennan acquired greater proficiency in English and use this language significantly more than Spanish. Nico is three years older than his brother. They grew up in a dual-language home: the mother speaks to them mainly in English, the father mainly in Spanish, and I speak to them almost exclusively in Spanish. I observed and recorded the siblings regularly. Diaries and recordings also include adults' speech addressed to the children.

The children's degree of proficiency in English by age six is comparable to that of monolinguals. By contrast, their developing proficiency in Spanish is unequal. This inequality results from differences in the amount of Spanish language input they have been exposed to, which has been typically more reduced for the younger sibling. 
Overall, Nico was exposed to Spanish about one third of his waking time; Brennan, less than one third. From about age 4;0, exposure to and use of Spanish are further reduced for both children to at most a quarter of the time ${ }^{3}$.

Nico: about $30 \%$ of his waking time.

Brennan: about $27 \%$ of his waking time.

Beyond age 4;0: Nico approximately $25 \%$, Brennan approximately $22 \%$ of their time.

\section{GRAMMATICAL SUBJECTS: REALIZATION AND PLACEMENT}

The learnability question for the child acquiring English and Spanish should be easier for English, which offers a highly regular model of overt, preverbal subjects, but harder for Spanish, since the child needs to learn the semantic and discourse-pragmatic constraints that regulate subject realization and the position of those that are overt.

The differences between Spanish and English motivate the question of whether there is crosslinguistic interaction: are the children delayed in reaching complete mastery of the requirement of an overt subject and its invariant preverbal position in English? Or, rather, do they tend to copy these features onto Spanish? Also, do the siblings develop similarly regardless of their differences in amount of input?

Language contact theory predicts the simplification of semantically close alternative structures correlated with different pragmatic functions in situations of intensive bilingualism (Dorian 1980, Prince 1992). Generative theories of interface phenomena similarly predict that pragmatic restrictions are vulnerable in BFLA when the languages in contact share parallel structures and one of the languages offers choices regulated by semantic or discourse-pragmatic factors (e.g., Döpke 1998, Müller \& Hulk 2001). Assuming that these predictions are correct, we may expect subjects in Spanish to be vulnerable to English influence, especially so if Spanish is the weaker language. 


\section{SubJeCT REALIZATION}

The children are rarely exposed to subjectless sentences in English. In my data, 98.5 percent of the adult statements occur with an overt subject. By contrast, adult statements in Spanish provide frequent subjectless models, as in example (1).

(1) Nico (N), grandmother (C)

$\mathrm{N}$ : ¿Dónde está la Lupe? $(1 ; 9: 16)$

C: $\mathbf{0}$ está en la casa de ella. $\mathbf{0}$ no está en la casa de granma.

'N: Where's Lupe?

C: [She]'s in her home. [She]'s not in granma's home.

Studies applying a variationist methodology have shown that the variable expression of a subject is responsive to cognitive, semantic, and discourse factors (Shin 2014, Travis \& Torres Cacoullos 2012, among many). An overt subject is required under two conditions: 1) when it is focal, either because it is new information or the focus of contrast, and 2) when it is needed to identify its referent.

Overt subjects are favored probabilistically by a number of variables, including subject switch reference, as in example (2); verbs in the first person singular; and verbs of volition, of saying or speaking, and of mental processes (e.g., pensar 'think', creer 'believe').

(2) a) Tu hermano quería saber b) si (yo) enseño en USC. [yo 'I' is "optional"]

a) 'Your brother wanted to know b) if I teach at USC'.

(3) a) Pepe es un escritor muy conocido. b) Es mi vecino.

a) 'Pepe is a well-known writer. b) [He]'s my neighbor.'

Discontinuity of reference favors the expression of the subject. Continuity of reference (or coreferentiality), as in (3a-b), has consistently been shown to disfavor overt subjects. On average, in various Spanish dialects over 40 percent of non-coreferential subjects are overt, while only about 25 percent of coreferential subjects are expressed (Shin \& Cairns 2012).

There are other linguistic factors that have been argued to affect subject expression (priming, discourse genre, verb tense; see, e.g., several in Carvalho, Orozco \& Shin 2015), but the only indisputable facts are that subjects must be overt if they are focal or needed to identify the referent. All other factors leave a sizable percentage of cases to a large extent unexplained. Consequently, researchers incorporate quantification to find out 
similarities and differences in subject expression rates across individuals and across dialects. The assumption is that in a large corpus of data the various factors that constrain subject expression become neutralized and so overall percentages of overt subjects may reveal dialectal differences and possible processes of change.

Spanish varieties differ with respect to the rate of subject expression. In the siblings' case, the average percentage for the Santiago (Chile) variety, 38 percent (Cifuentes 1980-81), is of interest because this is the variety spoken by their family. The differences across dialects appear to indicate that subject pronoun expression is not validated only by discourse-pragmatic factors. In earlier work I have suggested (Silva-Corvalán 2003) an interactional function: a non-required overt subject is a sign of the speaker's intent to call the listener's attention toward the subject referent. This function may be more or less weakened in the various Spanish dialects, thus leading to different rates of expression. A number of overt subjects, then, may be expressed simply because they are an available alternative in the grammar, and Spanish dialects make use of this alternative at different rates, as attested in the percentage differences across dialects. Caribbean dialects, for instance, have been shown to have the highest rates of overt subjects while dialects spoken in Spain have the lowest.

Let us examine at this point how the siblings use subject pronouns.

I have examined about 5,000 declarative utterances containing a verb that had or could have had a subject. The utterances were coded for several factors, but I will briefly discuss only coreferentiality here.

The quantitative results by age 1 year and eleven months $(1 ; 11)$ indicate that the siblings are developing two different grammars. They realize at a very early age that the null subject is grammatical in Spanish but ungrammatical in English. Consider the percentages in Table 1.

Table 1. Percentage of overt subject pronouns by language at age $1 ; 11$

\begin{tabular}{cccccccccc}
\hline & \multicolumn{4}{c}{ Spanish } & \multicolumn{4}{c}{ English } \\
Age & \multicolumn{2}{c}{ Nico } & \multicolumn{2}{c}{ Brennan } & \multicolumn{2}{c}{ Nico } & \multicolumn{2}{c}{ Brennan } \\
& N & $\%$ & N & $\%$ & N & $\%$ & N & $\%$ \\
$1 ; 11$ & $0 / 9$ & 0 & $10 / 53$ & 18.9 & $48 / 49$ & 98.0 & $13 / 15$ & 86.7 \\
\hline
\end{tabular}

The siblings' use of subjects in English does not differ from what is typical for monolinguals. Subjects are expressed as expected. Thus, in what follows I focus only on Spanish. 
In Spanish, use of subjects appears to be affected as exposure to English increases and exposure to Spanish becomes more reduced.

Table 2. Subject pronoun realization in Spanish at ages $2 ; 0-2 ; 11,3 ; 0-3 ; 11$ and $4 ; 0-6 ; 0$

\begin{tabular}{lcccc}
\hline & \multicolumn{2}{c}{ Nico } & \multicolumn{2}{c}{ Brennan (younger) } \\
Age & $\%$ & $\mathrm{~N}$ & $\%$ & $\mathrm{~N}$ \\
$2 ; 0-2 ; 11$ & 36 & $329 / 912$ & 51 & $397 / 775$ \\
$3 ; 0$ to $3 ; 11$ & 28 & $178 / 636$ & 71 & $503 / 711$ \\
$4 ; 0-6 ; 0$ & 42 & $428 / 103$ & 69 & $411 / 598$ \\
\hline
\end{tabular}

At first glance, the results in Table 2 confirm the hypothesis that a lower amount of exposure to the weaker language makes a child more susceptible to influence from English. Brennan uses a much higher proportion of overt subjects than his brother from early on. But beyond age 4;0, the older child also increases the percentage of use of pronouns.

However, as Table 3 shows, Nico's rate of overt pronouns is comparable to those of children studied in other countries: Manuela (a balanced EnglishSpanish bilingual studied in Wales) and at an earlier age even lower than Juan's (a Spanish monolingual studied in Madrid).

Table 3. Overall percentage of use of overt subject pronouns by

Manuela, Nico, and a Spanish monolingual child (Juan)

\begin{tabular}{lcccl}
\hline \multicolumn{1}{c}{ Child } & (Age range) & $N$ & overt & \multicolumn{1}{c}{ Language } \\
Manuela & $(1 ; 9-2 ; 6)$ & $83 / 235$ & $\mathbf{3 5 \%}$ & Balanced bilingual (Wales) \\
Juan & $(1 ; 7-2 ; 11)$ & $85 / 204$ & $\mathbf{4 2 \%}$ & Monolingual (Madrid) \\
Nico & $(2 ; 0-2 ; 11)$ & $329 / 912$ & $\mathbf{3 6 \%}$ & English dominant (Los Angeles) \\
& $(4 ; 0-6 ; 0)$ & $428 / 1030$ & $\mathbf{4 2 \%}$ & \\
\hline
\end{tabular}

Unlike Manuela, Nico is exposed more frequently to English than to Spanish, yet an approximate time of one third of exposure to Spanish is sufficient for him to model the distribution of subjects typical of the adults in his ancestors' variety (38\%, Cifuentes 1980-81).

The increase in the speech of Brennan suggests that as English patterns become more entrenched, he may subconsciously replicate the [subject + verb] pattern of English onto Spanish. Brennan surpasses his brother's rate of expression by 27 percentage points between the ages of 4;0 and 6;0 (see Table 2 ), thus showing a more intense effect from reduced exposure to Spanish. 
It is of course possible that the increased rate of overt subjects might be justified, i.e., that the subjects might be focal, or needed to identify referents. But the contexts where a subject is clearly the new information or required to identify a referent in the children's data are very rare(most talk is about the here and now),so these factors could not explain the increased rate of overt subjects.

This leaves us with the possibility to compute overt and null subjects by a frequent objective factor, subject reference.

The frequent expression of coreferential subjects not justified by another favoring factor (e.g., first person, verb class, tense), as in example (4), is interpreted as redundant by native speakers. The passage in (4) is selected from Brennan's data at age 4;1. It includes five finite verbs, three of which could have had a non-overt subject, but Brennan expresses all five subjects.

(4) Brennan: 4;1 [talking about making a robot when he grows up]

B: Y mi robot, y mi robot, va a, a ser muy, muy bueno. Sabes que cuando yo (a) dijo 'para atrás' y no es parte de mi familia, él, dijo él (b) 'para atrás' y él (c) empuja para atrás, tan, tan atrás porque él (d) tiene esos [antenas] que son tan, tan largas que está en outer space y él(e) te tira para outer space, en tu auto.

'B: And my robot, my robot's gonna, gonna be very, very good. You know when (a) I say 'back' and is not part of my family, he, (b) he said 'back' and (c) he pushes back, so, so much back because (d) he has these [antennas] that are so, so long they reach outer space and (e) he pulls you to outer space, in your car.

The subjects in (4) (a) and (b) may be validated for various reasons, but the third person subjects in (4) (c), (d), and (e) are not validated by the discourse context: they are activated, coreferential, non contrastive, and unnecessary to identify their referent.

An informal survey of fourteen colleagues, nine from Spain and five from South America did not indicate overall agreement about which subject pronouns should or should not be expressed in a text I asked them to consider. It is no surprise, then, that the so-called syntax-pragmatic interface is vulnerable and open to change. The child does not receive a consistent input that would facilitate learning subjective discourse-pragmatic conditioning factors in situations of reduced language exposure.

A quantitative analysis of coreferentiality in the last age period, when the siblings evidence the highest rates of subject pronouns, shows that the coreferentiality constraint was weak in Nico's speech, and absent in Brennan's (see Table 4). Nico expresses coreferential subjects more 
frequently than the 25 percent average in adult speech, but he replicates the monolingual trend by expressing switch reference subjects even more frequently. Brennan, in contrast, evidences absence of this constraint: he does not differentiate coreferential from non-coreferential subjects with respect to frequency of expression; the difference between these subjects is not significant $(\mathrm{p}<.74)$.

Table 4. Subject pronoun realization by coreferentiality $(4 ; 0$ to $6 ; 0)$

\begin{tabular}{lcccc}
\hline & \multicolumn{2}{c}{ Nico } & \multicolumn{2}{c}{ Brennan } \\
& \multicolumn{2}{c}{ Overt/Overt+Null } & \multicolumn{2}{c}{ Overt/Overt+Null } \\
& N & $\%$ & N & $\%$ \\
Coreferential & $200 / 520$ & 38.5 & $194 / 285$ & 68.1 \\
Non-coreferential & $205 / 461$ & 44.5 & $217 / 313$ & 69.3 \\
& \multicolumn{2}{c}{$(\mathrm{p}<.05)$} & \multicolumn{2}{c}{$(\mathrm{p}<.74)$} \\
\hline
\end{tabular}

In sum, the simultaneous acquisition of a non-null-subject and a null-subject language does not affect the acquisition of subjects in either language at the earliest age stage. Furthermore, Nico's exposure to Spanish for approximately a third of his waking time to age $4 ; 0$ is sufficient for him to gain control of the factors that favor or require overt subjects in Spanish. But Brennan's rates of subject expression after age 4;0 diverge further from those reported for monolinguals, and for balanced bilingual children. A possible mechanism accounting for the high rate of pronouns is the child's copying of the English [subject pronoun + verb] string.

I identified a similar increase of subject pronouns in my study of adult bilinguals (Silva-Corvalán 1994). I noted then that the categorical restrictions on subject expression remained intact in second and third generation immigrants (see example (5)), but there was a decrease in the strength of the coreferentiality constraint, as is the case for the siblings, and especially for Brennan (see Shin \& Otheguy 2009 for the decrease of sensitivity to continuity of reference in New York Spanish).

Example (5) illustrates contrast:

(5) Mi hermana estudió, pero yo preferí trabajar. (G. 2)

'My sister studied but I preferred to work'.

Brennan and Nico's linguistic behavior is comparable to that of the Los Angeles bilingual adults, even though they have been exposed to a different variety of Spanish. If the increase in both groups of bilinguals is due to 
English, then this would involve the copy of the [subject + verb] pattern of English in individual instances of use; the outcome is quantitative: the increase of overt pronouns.

\section{POSITION OF THE SUBJECT WITH RESPECT TO THE VERB}

In Spanish, the position of the subject with respect to the verb is variable, and it involves knowledge of syntax, semantics and discourse pragmatics.

Examples (6) and (7),produced by the adults who interact with the siblings, illustrate the ordering variation.

(6) A: Es lo que pasa cuando el sol se está acostando en el mar. [preverbal subject]

'It's what happens when the sunse-is going to bed in the sea.'

(7) A: Cuando se está poniendo el sol, el cielo se pone rojo. [postverbal subject]

when $s e$ - is setting the sun, the sky se- turns red

'When the sun is setting, the sky turns red'.

Verb subject and subject verb positions are grammatical in Spanish. English does not have an exactly parallel VS option. With a few exceptions, subjects of declarative sentences must be in preverbal position.

The siblings reached adult-like behavior with respect to subject placement in English at a very early age. No postverbal subjects are identified in the data beyond age 2;0. In Spanish there is the expected pre- and post-verbal variation based mainly on the information status of the subject, but compared to monolinguals, the siblings show higher percentages of preverbal subjects. Furthermore, Brennan produces some examples with a preverbal subject that native speakers of Spanish judge to be inappropriate.

Studies of adult Spanish have considered verb class in relation to subject placement. These studies have distinguished gustar 'like' type verbs, copulative, transitive, unergative and unaccusative verbs as possibly favoring the pre or postverbal placement of the subject. While the correlation between verb class and subject position cannot be denied, I have argued that the explanation lies rather in the information structure of the sentence.

Gustar-type verbs are those that subcategorize a subject with the semantic role of theme or patient, and an indirect object, normally animate, with the role of experiencer, as in (8). These verbs favor the postverbal placement of the subject, which is most frequently inanimate and represents new or newer information. 
(8) A Pepe le gustaron/le encantaron/se le olvidaron/se le perdieron los anteojos nuevos.

to Pete to-him pleased/loved/forgot/lost the new glasses

'Pete liked/loved/forgot/lost his new glasses'

Unaccusative verbs denote non-agentive situations whose subject, like with gustar-type verbs, has the semantic role of theme or patient. They have been shown to favor the postverbal position (Mayoral Hernández 2008) when the subject is more informative than the verb, usually because its referent is being introduced into the discourse (Hatcher 1956).

Transitives tend to have preverbal subjects (SVO). In these constructions, the subject is normally given or less informative in relation to the direct object, which occupies the position after the verb (Ocampo 2009).

The subject of unergatives, similarly to that of transitive verbs, is normally given or less informative than the verb, which refers to activities or processes, and less informative than other constituents. The preferred subject position with unergatives is preverbal.

Finally, copulative verbs have been shown to favor the preverbal position, though less so than transitives and ergatives (Mayoral Hernández 2008).

Table 5. Preferred subject position by verb class

\begin{tabular}{ll}
\hline Postverbal subject: & Gustar 'like'-type verbs \\
& Unaccusatives \\
Preverbal subject: & Unergatives \\
& Transitives \\
& Copulatives \\
\hline
\end{tabular}

From age $3 ; 0$ on the siblings show subject placement preferences by verb class that are statistically significant, without differences between the children. These preferences are similar to those of the adults (as seen in Table 6), but with higher percentages of preverbal subjects with the four types of verb. However, the differences with the adults are statistically significant only with unaccusatives $(\mathrm{p}<.00)$. 
Table 6. Nominal subject position by verb class: siblings $(3 ; 0$ to $6 ; 0)$ and adult input

\begin{tabular}{|c|c|c|c|c|c|c|c|}
\hline \multicolumn{8}{|c|}{ Preverbal placement } \\
\hline & \multicolumn{2}{|c|}{ NiCO } & \multicolumn{2}{|c|}{ BRENNAN } & \multicolumn{3}{|c|}{ AdULT INPUT } \\
\hline & $\mathrm{N}$ & $\%$ & $\mathrm{~N}$ & $\%$ & & $\mathrm{~N}$ & $\%$ \\
\hline Gustar-type & $3 / 20$ & 15.0 & $8 / 35$ & 22.9 & $p<.48$ & $8 / 40$ & 20.0 \\
\hline Unaccusative & $51 / 74$ & 68.9 & $55 / 72$ & 76.4 & $p<.31$ & $41 / 85$ & $48.2(p<.00)$ \\
\hline Unerg \& Trans & $169 / 186$ & 90.9 & $158 / 167$ & 94.6 & $p<.18$ & $90 / 120$ & 75.0 \\
\hline \multirow[t]{2}{*}{ Copulative } & $142 / 186$ & 76.3 & $244 / 313$ & 78.0 & $p<.68$ & $83 / 107$ & 77.6 \\
\hline & \multicolumn{2}{|c|}{$p<.05$} & \multicolumn{2}{|c|}{$p<.05$} & & & \\
\hline
\end{tabular}

A thorough examination of the data indicates that subjects are in most cases appropriately preverbal, but there are as well a few that are not.

Consider Brennan's utterance in $(9 a)$ with the verb pasarle 'happen (to someone)' ${ }^{4}$. Given the preverbal position of the adverbial expression unas veces 'sometimes', the subject eso 'that' is expected to be postverbal (Ocampo 2005, Silva-Corvalán 1977), but Brennan has placed it preverbally. In $(9 b)$, the open question from the adult should have been responded in the order VS, yet Brennan again places the subject mi espalda 'my back' before the verb doler, a verb of the gustar-type. Note that the adult placed la espalda 'the back' in postverbal position with the same verb in the opening statement.

(9) $\mathrm{C}$ : $\mathrm{Y}$ entonces cuando [grandpa] anda en la bicicleta y hace fuerza así con las piernas, le duele la espalda después.

'And so when [grandpa] rides the bike and exerts force like this with the legs, his back hurts afterwards'.

B: a) Unas veces eso me pasa, pero yo- pero yo soy muy fuerte. [he gets sore from riding his bicycle] $(4 ; 2)$

'Sometimes that happens to me, but I- I'm very strong'.

C: ¿Sí? ¿Qué te pasa algunas veces?

'Yeah? What happens to you sometimes?'

\footnotetext{
4 The symbol " " is used to indicate that an utterance produced by a child is not acceptable to or grammatical for an adult speaker.
} 
B: b) Mi- mi espalda me duele cuando yo- yo hago así. $(4 ; 2)$

'My- My back hurts when I do that'.

Brennan also produced two examples (out of eighty) of other classes of verb with preverbal subjects that would not be acceptable; example (10) illustrates.

(10) B: En el RV, yo a las 5 yo despertó y después yo fui arriba $\sim$ donde mi papá y mi mamá duermen y dormí ahí. $(5 ; 3)$

'In the RV, I woke up at 5 and afterwards I went upstairs where my dad and my mom sleep and (I) slept there'.

In example (10), the heavy discourse-new subject mi papá y mi mamá 'my dad and my mom' is introduced in an adverbial relative clause with an unmodified verb, dormir 'sleep'(coded as unergative). The subject is expected to be placed postverbally, not preverbally as Brennan does. The translation shows that the order mirrors the English order. I have not identified these clearer cases of inappropriate orders in Nico's data.

In hundreds of examples I find only four cases of clearly unjustified preverbal nominal subjects, and these only in the child with more reduced exposure to Spanish. The analysis points to a crucial role for information structure in determining subject placement (more so than other factors like animacy, for example).

It is reasonable to expect information structure to be critical in guiding the children's word- order decisions from the earliest stage. Informativeness is in fact a universal discourse principle, i.e., the linearization of sentential constituents in human languages follows the order from more activated or known to less activated or known in pragmatically unmarked communicative contexts.

Tomasello \& Haberl (2003) have demonstrated experimentally that children are sensitive to newness before the age of $2 ; 0$. Note also that languages with a fixed SV order have a number of constructions whose function is to introduce new information in a non-subject position. English, for instance, introduces new referents as objects of the light verb have (I have a new bike. It doesn't have training wheels.) and allows the inversion of a new subject in constructions with an initial adverb (There's your cup). Likewise in French, the il y'a 'there is' construction is used to introduce a referent before referring to it in subject position and talking about it (Ocampo 1993). Consequently, if subject distribution is regulated mainly by informativeness, then it is no surprise that the siblings do well in this grammatical domain; different amounts of exposure to Spanish do not 
correlate with a significant distinction in Nico's and Brennan's behaviors with respect to subject placement.

Be that as it may, speakers whose strong language is Spanish show overall lower rates of preverbal pronominal and nominal subjects than the bilinguals. This observation, and the fact that Nico and Brennan's largest increase of preverbal subjects is attested when the amount of exposure to Spanish is reduced to less than a third, support proposing some degree of influence from English. As English becomes more prevalent, both children show signs (albeit hardly noticeable) of weakening of the Information Constraint in spontaneous speech production. Still, it is only in the data from the child with lower proficiency that it is possible to identify a few unquestionable violations of the preferred subject position in monolingual grammars.

I note that the same pattern of slightly higher preverbal subjects attested in the siblings' data compared to those in their adult input is also observed across immigrant generations (Silva-Corvalán 1994). For instance(see Table 7), the percentage of preverbal pronominal subjects in the Spanish of first generation immigrants increases from $85 \%$ to $91 \%$ among those born in the United States, and to $94 \%$ in the speech of third generation speakers.

Table 7. Preverbal pronominal subjects.

Siblings $(3 ; 0-6 ; 0)$, and three immigrant generations

\begin{tabular}{|c|c|c|c|c|c|c|c|}
\hline \multirow[b]{3}{*}{ AgE } & & & & & \multicolumn{3}{|c|}{ GENERATION } \\
\hline & \multicolumn{2}{|c|}{ NiCO } & \multicolumn{2}{|c|}{ BRENNAN } & \multicolumn{2}{|c|}{ FIRST } & $\mathrm{p}<0.75(\mathrm{w} / \mathrm{G} 2)$ \\
\hline & $\mathrm{N}$ & $\%$ & $\mathrm{~N}$ & $\%$ & $\mathrm{~N}$ & $\%$ & $\mathrm{p}<0.62(\mathrm{w} / \mathrm{G} 3)$ \\
\hline $3 ; 0-3 ; 11$ & $117 / 124$ & 94.4 & $381 / 386$ & 98.7 & $71 / 84$ & 84.5 & \\
\hline \multirow[t]{6}{*}{$4 ; 0-6 ; 0$} & $411 / 418$ & 98.3 & $407 / 409$ & 99.5 & \multicolumn{2}{|c|}{ SECOND } & $\mathrm{p}<0.93(\mathrm{w} / \mathrm{G} 3)$ \\
\hline & & & & & $\mathrm{N}$ & $\%$ & \\
\hline & & & & & $98 / 108$ & 90.7 & \\
\hline & & & & & \multicolumn{2}{|c|}{ THIRD } & \\
\hline & & & & & $\mathrm{N}$ & $\%$ & \\
\hline & & & & & $135 / 144$ & 93.8 & \\
\hline
\end{tabular}

The quantitative results may be interpreted to support the assumption of influence from English. However, a Spanish internal priming effect may also be defended, in the sense that the very high frequency of preverbal pronoun subjects in monolingual Spanish motivates an even higher frequency of the preverbal position in bilingual Spanish. The siblings do not differ from 
each other in this respect. There are no statistically significant differences between them.

The results of the study of subject realization and position agree in pointing to a trend to converge with English as the siblings grow up and English becomes stronger. Interestingly, this trend is less robust in the case of nominal subject position(see Table 6),most likely because the siblings follow the pragmatic principle of ordering old before new. By contrast, the discourse-pragmatic rules that govern subject expression in Spanish are less transparent and take longer, if at all, to be acquired. The bilinguals' behavior in both grammatical domains is quantitatively different from that of monolinguals, but the copy from English of an abstract SV order is very difficult to uphold.

\section{LEXICAL INNOVATIONS}

External causation is indisputable in the lexicon, however. This is not surprising since bilingual lexical access is characterized by non-selectivity, that is, at least in test situations bilinguals non-selectively activate lexical representations in both languages, regardless of the language currently in use (see, e.g., several in Pavlenko's 2011 volume). Therefore, lexical representations in one language could affect how words and word combinations are learned and used in a contact language. The siblings' bilingual development provides evidence of two mechanisms manifest in their lexical innovations:

1) Morphological mixing, i.e., the copy of single words from English that are adapted to the morphophonology of Spanish; and

2) Equating of words, (bound) collocations, complex verbal structures, or idioms from English with lexical units from Spanish, which results in unusual constructions in this language.

Cases of morphological mixing are of interest because they indicate that children are sensitive to structural clues and have acquired implicit knowledge of some aspects of Spanish morphology at an early age. This is illustrated by Nico's creation of lifa (in example 11), from leaf plus the ending $-a$ characteristic of many feminine nouns, and later of lipo from lip, which replicates the gender of the Spanish word for lip, labio-masc. Examples (12) and (13) illustrate adaptations of English verbs to Spanish morphology starting from age 2 years and 7 months. 
(11) N: Pongamos la lifa en el agua. $(2 ; 6.25)$

'Let's put the leaf in the water'.

(12) N: Bibi, cómbete con tu cepillo. (2;7.25) [from comb, instead of péinate]

'Bibi, comb-yourself with your brush'.

(13) B: ¡Ah, estoy pulando tu cadena! $(3 ; 4)$ [chain for eye glasses] [from pull]

'Ah, I'm pulling your chain!'

A: Me estás tirando la cadena.

'You're pulling my chain'.

Copying is evident also in word combinations that do not alter the surface syntax of Spanish, but do affect the way in which words collocate in this language.

\section{US Spanish English Non-US Spanish}

no puedo esperar from [I] can't wait 'tener muchos deseos de X'

cambiar mi mente from change my mind 'cambiar de opinión'

hacer contento from make happy 'alegrar/poner contento'

The exchanges in (14) and (15) are illustrative:

(14) N: El Galaxia ganó, y eso me hizo tan contento. Eso me hizo muy contento. $(4 ; 0)$

Instead of "Me puso muy contento". or "Me alegró mucho".

'Galaxy won, and that made me so happy. That made me very happy'.

(15) N: No puedo esperar hasta que el tío Diego me enseñe [a andar en bicicleta]. $(4 ; 6)$

[I] can't wait till tío Diego to-me teach

'I can't wait for tío Diego to teach me [to ride a bike]'.

These examples are instances of direct copies from English of the semantics of an idiomatic combination, which results in the creation of an idiomatic combination in Spanish. They serve to illustrate the equating mechanism that generates them. The children establish cross-language correspondences that at times lead them astray.

Example (14) shows that Nico has extended the parallels between make and hacer in some form-meaning pairings (as in hacer una torre 'make a tower', hacer la cama 'make the bed') to contexts where these verbs do not overlap. 
This is evidence that interaction may occur not only when there is partial structural overlap (as with subject expression), but also when words in the two languages share some semantic features and their collocations partially overlap (see also Gathercole\& Moawad 2010).

What is important to highlight about the equating of bound collocations, be they idioms or complex verbal structures, is that the reproduction with lexical units from Spanish does not violate the rules for the surface arrangement of these units in this language. Nonetheless, this type of copy alters collocational features and consequently the semantic interpretation of the innovative complex structure in Spanish.

These lexical innovations are also attested in the Spanish of adult bilinguals, and contribute to giving this Spanish variety an Americanized flavor.

\section{THE VERB SYSTEM}

Regarding the acquisition of tense-mood-aspect (TMA) morphology, I will discuss only briefly a Table with information about the verb tenses used by the children during the last age period studied. In English, no differences are observed between the siblings and English-speaking monolingual children. In Spanish, most of the simple indicative mood tenses are not problematic. The siblings were able to talk about the present, the past and the future with little difficulties. But the less frequent and more complex tenses that refer to non-experienced and hypothetical situations were either unstable or not acquired by the end of the first six years.

Reduction in exposure to Spanish led to not learning or weakening the on-line command of compound and irrealis tenses, as shown in examples (16) and (17).

(16) N: Porque él quería que la gente mala encontrara-ImpSub [on target] pedazos de él para que ellos $\sim$ hacía-Imp más robots. $(5 ; 6)$ [ImpSub required: hicieran]

'Because he wanted the bad people to find pieces of him so that they made more robots'. [expected: could make]

(17) B: No cuando ya tengo-PresInd dieciséis años. $(5 ; 4)$ [expected: tenga-PresSub]

'Not when [I] am sixteen years old'. 
Consider Table 8, which includes four children: Daisy, from a Spanish-only home, Mike, from a Spanish and English home, Nico and Brennan, from a mainly English home, and two adults: V21, second immigrant generation, and A46, third immigrant generation. The information in this Table is based on a minimum of three hours of recording for each speaker.

Table 8. Spanish TMA usage compared across bilinguals and a (near) monolingual child (5;0-6;0), and two bilingual adults

\begin{tabular}{lcccccc}
\hline & Daisy & Mike & Nico & Brennan & V21 & A46 \\
& Sp & Bil & Bil & Bil & G2 & G3 \\
Ind mood: & & & & & & \\
Present & + & + & + & + & + & + \\
PresProgressive & + & + & + & + & + & + \\
PeriphrFuture & + & + & + & + & + & + \\
Preterite & + & $*$ & $*$ & $*$ & $*$ & $*$ \\
Imperfect & + & $@$ & + & $@$ & + & $@$ \\
ImpProgress & + & + & + & + & & \\
PastPeriFuture & + & + & & & & \\
Conditional & 1 & & & & & \\
PresPerfect & + & + & + & + & & \\
Sub mood: & & & & & & \\
Present & + & + & + & 0 & & \\
Imperfect & + & + & 0 & & & \\
\hline
\end{tabular}

"+" tense form is used according to the norms of general spoken Spanish;

“*”closed list of stative verbs used with imperfect morphology in preterite-perfective contexts;

“@” some preterites instead of imperfects;

"0" form has failed to occur in a high number of obligatory contexts, Ind = Indicative; Sub = Subjunctive; Periphr, Peri = Periphrastic; $\operatorname{Imp}=$ Imperfect; Pres $=$ Present.

Table 8 shows visually that the simpler and more frequent tenses are used in the same manner by all the speakers in the Table. Differences among the children and adults correlate with home language and consequent amount of exposure to Spanish. Note the row for Preterite. Daisy is the only one who uses stative verbs with preterite morphology consistently in 
perfective contexts. Mike, Brennan and A46 also evidence unstable preterite morphology.

Interestingly, the TMA system of the children and the adult bilinguals match in the use of a closed list of stative verbs in the imperfect instead of the preterite, as illustrated in (18).

(18) N: Estaba pateando la pelota a un hombre y alguien pateó la pelota a mi pierna y (a) fue-Pret un awi grande y (b) eso estaba-Imp terrible. $(2 ; 8.15)$ [expected: estuvo-Pret]

'He was kicking the ball to a man and someone kicked the ball to my leg and (a) it was-Pret a big booboo and (b) that was-Imp terrible'.

I find it remarkable that despite reduced exposure to Spanish, Nico has developed a tense system which is very close to that of Daisy, a near Spanishmonolingual child. Brennan, on the other hand, has developed a system that is almost the same as that of the generation 3 speaker; irrealis tenses are absent in this system.

The use of irrealis forms in English, on the other hand, makes it clear that the lack of these forms in Spanish is a linguistic question and not a cognitive one. In English, Mike, Nico and Brennan can easily converse about nonfactual past and future situations, as example (19) shows.

(19) $\mathrm{B}=$ Brennan $(5 ; 6)-\mathrm{M}=$ mother

M: That's a good story, huh? The little froggie. Do you think he should have taken the frog?

B: No.

M: No? What do you think?

B: He should've left him with his family.

M: He should've? Why?

B: Because frogs are wild.

Further similarities between the siblings and second and third immigrant generation adult bilinguals may be identified. This is interesting because the children had very rarely, if at all, been exposed to the speech of these speakers.

For instance, overuse of the copula estar 'be' in predicate adjectives, illustrated in (20).

(20) B: Y un oso grande vino.

C: ¡Wow, qué miedo!

B: No. $\sim$ Estaba bueno. $(2 ; 10.26)$ [Target: era (ser)] 
'B: And a big bear came.

C: Wow, how scary!

B: No. He was [estar] good. (2;10.26) [Target: era (ser)]

Conversely, other off-target syntactic constructions are transitory and no longer attested beyond the age of 4 years and 1 month; in particular, the placement of adjectives before the noun (verde hoja 'green leaf'), preposition stranding (example 21), and copies of the English genitive (example 22). In this regard, the siblings' grammars are closer to those of second generation rather than third generation speakers.

(21) N: ¿ ¿Quién estás hablando con, papi? $(3 ; 7)$

'Who are [you] speaking with, papi?'

(22) B: Cuando yo esté a Kiko's escuela. (2;8.25)

'When I am in Kiko's school'

Thus, I find no evidence of a new mixed language. Structural copies that violate the typological patterns of a language constitute qualitative changes that are perceptually salient(e.g., the realization of complementizers, negation, question formation, auxiliary verbs, noun-adjective order, genitive structures; cf. Hickey 2010). Therefore, the deviant structures are in time discarded, because the bilingual children either self-correct or are corrected by adults.

\section{CONCLUSION}

At the outset I posed three basic questions, which I take up now in closing.

The answer to the question of the effect of amount of exposure on the development of each of the bilinguals' language systems is evident: the more exposure, the closer to monolingual patterns of development. Although compared to monolinguals, the siblings received less exposure to English, though not below 70 percent, their proficiency and rate of development in this language is similar and not affected by Spanish.

The siblings' proficiency in Spanish, however, is unequal in some grammatical and lexical domains, and in their susceptibility to influence from English. These differences correlate with their comparatively unequal amounts of Spanish input and use of this language, an outcome 
that corroborates previous findings in studies of simultaneous bilinguals (e.g., Gathercole \& Thomas 2009, Hoff et al. 2012, Unsworth 2013 and forthcoming, Yip \& Matthews 2007).

Around the ages of $3 ; 6$ to $4 ; 0$, when exposure to English increased considerably, the siblings began to diverge from the typical monolingual development in the domains of subject realization and placement, in some aspects of the verbal system, and in the production of lexical complexes.

The implication from these findings is that less than 30 percent cumulative exposure to a minority language will likely trigger language changes in bilingual development and the consequent emergence of a new variety of this language. Clearly, then, any theory of bilingualism should incorporate a consideration of such experiential variables as the quantity and quality of the input.

Our second research question asked how crosslinguistic interaction is manifested. In earlier work on adult bilingualism (Silva-Corvalán 1994, 1998), I concluded that what bilinguals borrow across languages in societal bilingualism is not syntax but semantics and pragmatics. The resilience of the syntax seems evident as well in BFLA (Müller \& Hulk 2001, Sorace and Serratrice 2009). I have differentiated two interaction mechanisms, copy (a qualitative process), which causes changes that are clearly the result of contact, and quantitative influence, both conditioned by a number of interrelated factors (e.g., linguistic and cognitive complexity, language dominance, exposure and use patterns, the structure of the contact languages).

Crosslinguistic effects are manifested differently in the various language domains: copy is identified in the lexicon (simple and complex items), while quantitative influence may be identified in the acquisition of subjects. The implication is that changes caused by copying are clearly the result of contact, while those that result from influence may have an internal or an external motivation, or both (cf. Dorian 1993, Otheguy \& Zentella 2012, Thomason 2010), as is most likely the case with subject realization. This outcome supports Thomason's (2010) observation "that both internal and external motivations are needed in any full account of language history and, by implication, of synchronic variation".

Most favorable to crosslinguistic interaction is the existence in the input languages of superficial structures that bilinguals perceive to be parallel. Cognitive pressure from a dominant language motivates an increase in the use of the perceived parallel structure in the weaker language (e.g., $w$ h-insitu questions in the English of Cantonese-English bilingual children (Yip $\&$ Matthews 2007), passive constructions in Spanish, preverbal subjects). When the structure in this language has a syntactic variant and the variants are constrained by semantic and/or discourse-pragmatic factors not operative 
in the single structure of the dominant language, bilinguals do not acquire these constraints or if they do, their sensitivity to the rules becomes weaker or is lost.

Quantitative influence affecting the constraints, as well as the copy of the meaning of word combinations do not cause syntactic violations and are thus difficult to point out and modify. Thus, the new features stabilize, they spread in the minority language community and become characteristic of adult speech: intergenerational language change has thus taken place.

In sum, "where are the links?" What is the relationship between BFLA in the early years and its possible role in the grammars of adult heritage speakers? Some concrete connections discussed are the increased production of overt subject pronouns and preverbal subjects; a reduced TMA system; and the reproduction of the meaning of word combinations from English into Spanish.

The parallels identified between the siblings' linguistic behavior and that of adult heritage speakers have two further implications: first, they imply that some aspects of the heritage language of adults are the outcome of an interrupted process of acquisition of this language between the ages of 3;0 and 5;0, when more intensive exposure to another language, English in our case, reduces exposure to the heritage language and diminishes the opportunities to use it; and second, given that the siblings' input in Spanish is not attrited or reduced, the results suggest that some of the changes that have been identified across generations of bilinguals (e.g. by Gutiérrez 2003, Lynch 1999, Otheguy \& Zentella 2012, Silva-Corvalán 1994, Zentella 1997) develop naturally in the acquisition of the heritage language in childhood, regardless of whether the innovative features occur in the input or not. This strongly suggests that simultaneous bilingualism in situations of language contact may play an important role in language change (cf. Meisel 2011 for a different view). Meisel (2011) has stated that changes reflecting use, such as an increase or decrease in the frequency of occurrence of specific forms, are not relevant to the question of grammatical change. Rather, I maintain that the higher frequencies of some structures in bilingual grammars are substantial and consistent. They reveal true processes of change of the bilinguals' underlying knowledge of the language involved and may originate further change. Pressure from a dominant language, cognitive at the individual level, and social at the community level, thus leads to the birth of a new variety of a minority language. 


\section{REFERENCES}

Argyri, Efrosyni y Antonella Sorace. 2007. Crosslinguistic influence and language dominance in older bilingual children. Bilingualism: Language and Cognition 10. 79-99.

Carvalho, Ana M., Rafael Orozco y Naomi L. Shin. 2015. Subject pronoun expression in Spanish: A cross-dialectal perspective. Washington, D.C.: Georgetown University Press.

Cifuentes, Hugo. 1980-81. Presencia y ausencia del pronombre personal sujeto en el habla culta de Santiago de Chile. Homenaje a Ambrosio Rabanales. Boletín de Filología de la Universidad de Chile 31. 743-752.

CuzA, Alejandro. 2010. The L1 attrition of the Spanish present tense. Hispania 93. 256-272.

Doğruöz, A. Seza y Ad Backus. 2009. Innovative constructions in Dutch Turkish: An assessment of on-going contact-induced change. Bilingualism: Language and Cognition 12. 41-63.

DöPKE, SuSANNE. 1998. Competing language structures: The acquisition of verb placement by bilingual German-English children. Journal of Child Language 25. 555-584.

Dorian, NANCY. 1980. Maintenance and loss of same-meaning structures in language death. Word 31. 39-45.

1993. Internally and externally motivated change in contact situations: doubts about dichotomy. En Charles Jones (ed.). Historical linguistics: Problems and perspectives, pp. 131-155. London: Longman.

Gathercole, Virginia C. M. y Ruba A. Moawad. 2010. Semantic interaction in early and late bilinguals: All words are not created equally. Bilingualism: Language and Cognition 13. 385-408.

Gathercole, Virginia C. M. y Enlli M. Thomas. 2009. Bilingual first language development: Dominant language takeover, threatened minority language take-up. Bilingualism: Language and Cognition 12. 213-237.

Gutiérrez, Manuel. 2003. Simplification and innovation in US Spanish. Multilingua 22. 169-184.

Hatcher, Anna Granville. 1956. Theme and underlying question: Two studies of Spanish word order. Word 12, Monograph \#3.

HiCKEY, RAYMOND. 2010. Language contact: Reconsideration and reassessment. En Raymond Hickey (ed.). The handbook of language contact. Blackwell Publishing [en línea]. Disponible en http://www.blackwellreference.com/subscriber/book.html? [Consulta 04/11/2014].

Hoff, Erika, Cynthia Core, Silvia Place, Rosario Rumiche, Melissa Señor y Marisol PARRA. 2012. Dual language exposure and early bilingual development. Journal of Child Language 39. 1-27.

KIng. Ruth. 2000. The lexical basis of grammatical borrowing: A Prince Edward Island French case study. Philadelphia: John Benjamins.

LyNCH, ANDREw. 1999. The subjunctive in Miami Cuban Spanish: Bilingualism, contact, and language variability. Tesis para optar al grado de Doctor en Filosofía con mención en Lingüística Hispánica, University of Minnesota, Minneapolis.

Mayoral Hernandez, Roberto. 2008. The locative alternation: Unaccusative constructions and subject position. Tesis para optar al grado de Doctor en Filosofía con mención en Lingüística, University of Southern California.

Meisel, Jürgen. 2011. Bilingual language acquisition and theories of diachronic change: Bilingualism as cause and effect of grammatical change. Bilingualism: Language and Cognition 14. 121-145. 
Montrul, Silvina. 2005. Second language acquisition and first language loss in adult early bilinguals: Exploring some differences and similarities. Second Language Research 21. 199-249.

2011. Multiple interfaces and incomplete acquisition. Lingua 121. 591-604.

Müller, Natascha y AafKe Hulk. 2001. Crosslinguistic influence in bilingual language acquisition: Italian and French as recipient languages. Bilingualism: Language and Cognition 4. 1-21.

Nicoladis, Elena. 2012. Cross-linguistic influence in French-English bilingual children's possessive constructions. Bilingualism: Language and Cognition 15. 320-328.

OCAMPO, Francisco. 1993. The introduction of new referents in French and Spanish discourse: One constraint, two strategies. En William J. Ashby, Marianne Mithun, Giorgio Perissinotto y Eduardo Raposo (eds.). Linguistic perspectives on the Romance languages, pp. 351-362. Amsterdam: John Benjamins.

2005. The word order of constructions with an intransitive verb, a subject, and an adverb in spoken Spanish. En David Eddington (ed.). Selected Proceedings of the 7th Hispanic Linguistics Symposium, pp. 142-157. Somerville, MA: Cascadilla Proceedings Project.

2009. El orden de palabras en el español hablado. La construcción Sujeto Verbo Objeto Directo. En Montserrat Veyrat Rigat y Enrique Serra Alegre (eds.). La lingüistica como reto epistemológico y como acción social, pp. 501-511. Madrid: Arco/Libros.

Otheguy, Ricardo. 2003. Las piedras nerudianas se tiran al Norte: Meditaciones lingüísticas sobre Nueva York. Insula. Revista de Letras y Ciencias Humanas 679-680. 13-19.

Otheguy, Ricardo y Ana Celia Zentella. 2012. Spanish in New York: Language contact, dialectal leveling, and structural continuity. Oxford: Oxford University Press.

PARADIS, JohanNe. 2010. Bilingual children's acquisition of English verb morphology: Effects of language exposure, structure complexity, and task type. Language Learning 60. 651-680.

Pavlenko, Aneta (ed.). 2011. Thinking and speaking in two languages. Clevedon: Multilingual Matters.

Poplack, Shanay Stephen Levey. 2010. Contact-induced grammatical change: A cautionary tale. En Peter Auer y Jürgen E. Schmidt (eds.). Language and space: An international handbook of linguistic variation (vol. 1): Theories and methods, pp. 391-418. Berlin: Mouton de Gruyter.

Poplack, Shana, Lauren Zentz y Nathalie Dion. 2012. Phrase-final prepositions in Quebec French: An empirical study of contact, code-switching and resistance to convergence. Bilingualism: Language and Cognition 15. 203-225.

Prince, Ellen. 1992. On syntax in discourse, in language contact situations. En Claire Kramsch y Sally McConnell-Ginet (eds.). Text and context: Cross-disciplinary perspectives on language study, pp. 98-112. Boston: D.C. Heath.

Shin, NaOmi Lapidus. 2014. Grammatical complexification in Spanish in New York: 3psg pronoun expression and verbal ambiguity. Language Variation and Change 26. 303-330.

Shin, Naomi Lapidus y Helen Smith Cairns. 2012. The development of NP selection in schoolage children: Reference and Spanish subject pronouns. Language Acquisition: A Journal of Developmental Linguistics 19. 3-38.

Shin, NAOMi Lapidus y Ricardo Otheguy. 2009. Shifting sensitivity to continuity of reference in New York City: Subject pronoun use in Spanish in New York City. En Manel Lacorte y Jennifer Leeman (eds.). Español en Estados Unidos y otros contextos de contacto: Sociolingüística, ideología y pedagogía. 111-136. Madrid: Iberoamericana.

Silva-Corvalán, Carmen. 1977. A discourse study of word order in the Spanish spoken by Mexican-Americans in West Los Angeles. Tesis de Maestría en Lingüística, University of California, Los Angeles. 
1994. Language contact and change: Spanish in Los Angeles. Oxford: Clarendon. 1998. On borrowing as a mechanism of syntactic change. En Armin Schwegler, Bernard Tranel y Myriam Uribe-Etxebarria (eds.). Romance linguistics: Theoretical perspectives, pp. 225-246. Amsterdam: John Benjamins.

2003. Otra mirada a la expresión del sujeto como variable sintáctica. En Francisco Moreno Fernández, Francisco Gimeno, Juan Antonio Samper, Mariluz Gutiérrez, María Vaquero y César Hernández (eds.). Lengua, variación y contexto: estudios dedicados a Humberto López Morales, pp. 849-860. Madrid: Arco/Libros.

2014. Bilingual language acquisition: Spanish and English in the first six years. Cambridge: Cambridge University Press.

Sorace, Antonella y Ludovica Serratrice. 2009. Internal and external interfaces in bilingual language development: Beyond structural overlap. International Journal of Bilingualism 13. 195-210.

Thomason, Sarah. 2010. Contact explanations in linguistics. En Raymond Hickey (ed.). The handbook of language contact. Blackwell Publishing [en línea]. Disponible en http://www. blackwellreference.com/subscriber/book.html? [Consulta 04/11/2014].

Tomasello, Michael y Katharina Haberl. 2003. Understanding attention: 12- and 18-montholds know what is new for other persons. Developmental Psychology 39. 906-912.

Travis, Catherine y Rena Torres Cacoullos. 2012. What do pronouns do in discourse? Cognitive, mechanical, and constructional factors in variation. Cognitive Linguistics 23. 711-748.

Unsworth, Sharon. 2013. Assessing the role of current and cumulative exposure in simultaneous bilingual acquisition: The case of Dutch gender. Bilingualism: Language and Cognition 16.86-110.

( forthcoming). Amount of exposure as a proxy for dominance in bilingual language acquisition. En Carmen Silva-Corvalán y Jeanine Treffers-Daller (eds.). Language dominance in bilinguals: Issues of measurement and operationalization. Cambridge: Cambridge University Press.

Yip, Virginia y Stephen Matthews. 2007. The bilingual child: Early development and language contact. Cambridge: Cambridge University Press.

Zentella, Ana Celia. 1997. Growing up bilingual. Malden: Blackwell. 